\title{
Paediatric Casualties During OP TELIC
}

\author{
I Gurney
}

\author{
ABSTRACT \\ Aim \\ To audit all paediatric attendances to a \\ British Army Field Hospital during \\ warfighting.
}

Population

All patients < 16-years-old who presented to 34 Field Hospital Accident \& Emergency (A\&E) Department during warfighting phase of OP TELIC (27 Mar 03 to 01 May 03).

\section{Method}

A retrospective analysis of $A \& E$ attendance register, A\&E clinical records, and A\&E trainees' logbooks from the department of 34 Field Hospital.

\section{Results}

Seventy eight children were treated, mean age 7.9 years. $65.4 \%$ were male and $34.6 \%$ female. Children accounted for $2.9 \%$ of all patients (total attendances 2720 ) and $32.9 \%$ of noncoalition patients (non-coalition attendances 237). 44 (56\%) children had burns as the principal injury; $7(9 \%)$ had shrapnel injuries, $5(6 \%)$ had blunt trauma from a road traffic accident. Only one child had GSW. $17 \%$ of attendances were related to 'medical' complaints rather than trauma. $78 \%$ of children required transfer to a specialist facility.

\section{Conclusions}

Recognition of the potential for paediatric casualties is required to facilitate appropriate planning, training and equipping of medical units deployed on future operations.

\section{Introduction}

Capt I Gurney

BMedSci BM BS

RAMC

SHO Accident \&

Emergency Medicine

MDHU Frimley Park Hospital,

Portsmouth Road, Frimley,

Surrey GU16 5UJ
Few would disagree that children are the most tragic victims of modern war fighting, innocent and often without the necessary knowledge or insight to avoid their involvement, the child bears disproportionately the consequences of armed conflict. Figures quoted for conflicts in the last decade show that civilians account for more than $80 \%$ of all individuals killed and wounded (1), and that an unfortunately high proportion of these civilian casualties are children. Children are injured and killed in war, as are civilian adults, by the effects of blast, burns and penetrating trauma. These injuries may be sustained directly during fighting as children become enmeshed, they may be sustained due to the effects of military ordnance on their homes, or they may be sustained later through the twin threat of unexploded ordnance and land mines. The collateral effect of war is manifest in the child through starvation, exposure, disease and loss of the infrastructure required for a healthy childhood (3).

34 Field Hospital RAMC deployed from Northern Kuwait to Al Shaibah Airbase, a location near to Basra in Southern Iraq, in order to provide Role 3 medical support to 1 UK Division's activities in this region. An advanced detachment with a 25-bed capability began to receive casualties on the 27 Mar 2003, with a full field hospital capability of 200 beds opening a number of days later.

This article aims to examine the proportion of casualties treated by this unit that were children, to analyse the type of injuries sustained by the paediatric population of Southern Iraq during the conflict, and to discuss how best to manage future paediatric casualties of conflict.

\section{Methods}

A retrospective analysis of held medical records, attendance registers and medical staff logbooks from the Accident \& Emergency department of $34 \mathrm{Fd}$ Hospital was carried out. Records were examined from the 27 Mar up to, and including the 1 May 2003, the declared end of the conflict. A definition of a paediatric casualty as under the age of 16 years was applied. Data collected included age, sex, diagnosis and disposal (i.e. admitted to $34 \mathrm{Fd}$ Hosp, transferred to an alternative coalition medical facility or discharged).

\section{Paediatric Experience \\ Questionnaire}

As an indicator of paediatric expertise and experience, a reasonable gauge of competence to manage the paediatric workload being seen, all medical staff employed in the Accident \& Emergency department completed an informal questionnaire. 


\section{Results}

In total the Accident \& Emergency department of $34 \mathrm{Fd}$ Hospital saw 2720 patients, consisting of coalition, Iraqi and local civilian casualties in the 36 days considered in this analysis. Of these 237 patients were of non-coalition status (8.71\%).

Paediatric casualties, meeting the definition, given numbered $78(2.87 \%$ of total, $32.91 \%$ of all non-coalition patients).

Ages were recorded for 38 of the 78paediatric casualties, from these a mean age of paediatric casualty of 7.89 years was calculated. Of the children seen $51,(65.4 \%)$ were boys, $27(34.6 \%)$ were girls. No children had a measured weight recorded in their notes. Analysis of the nature of injury / illness sustained is displayed in Table 1 .

Table 1. Injuries sustained by children seen at 34 Field Hospital RAMC during Op Telic, 27 Mar - 1 May 2003.

\begin{tabular}{|l|c|c|}
\hline Complaint & $\begin{array}{c}\text { No. Of } \\
\text { Patients }\end{array}$ & $(\%)$ \\
\hline BURNS & $\mathbf{4 4}$ & $\mathbf{5 6 . 4}$ \\
\hline Full Thickness & 7 & \\
\hline $\begin{array}{l}\text { Partial/Superficial } \\
\text { Thickness }\end{array}$ & 33 & \\
\hline $\begin{array}{l}\text { Delayed Presentation } \\
\text { i.e. } \\
\text { Contracture/Infection }\end{array}$ & 4 & \\
\hline OTHER TRAUMA & $\mathbf{2 1}$ & $\mathbf{2 6 . 9}$ \\
\hline GSW & 1 & \\
\hline RTA & 5 & \\
\hline Shrapnel Injury & 7 & \\
\hline $\begin{array}{l}\text { Blast/Unexploded } \\
\text { Ordnance }\end{array}$ & 2 & \\
\hline Other - incl Falls & 6 & \\
\hline $\begin{array}{l}\text { MEDICAL } \\
\text { \& OTHER }\end{array}$ & $\mathbf{1 3}$ & $\mathbf{1 6 . 7}$ \\
\hline
\end{tabular}

Of the 78 children seen, 61 (78.2\%) were either admitted to $34 \mathrm{Fd}$ Hospital or transferred on for specialist care, for example, to a neurosurgically equipped unit. Seventeen children (21.8\%) were discharged following assessment and treatment within the Accident \& Emergency department.

All medical staff completed the paediatric experience/qualification questionnaire, the

Table 2. Paediatric qualifications and experience of medical staff deployed with the A\&E department, 34 Field Hospital RAMC during Op Telic.

\begin{tabular}{|l|c|c|c|}
\hline Grade & No. & APLS & $\begin{array}{c}\text { Recent } \\
\text { Paed } \\
\text { Unit } \\
\text { Experience }\end{array}$ \\
\hline Consultant & 3 & 3 (1 instructor $)$ & 1 \\
\hline Specialist Registrar & 4 & $2(1$ instructor $)$ & 2 \\
\hline Senior House Officer & 4 & 2 & Nil \\
\hline
\end{tabular}

results of which are displayed in Table 2 . It should be noted that 'experience' relates to specific paediatric unit experience in the previous 2 years, consisting of a minimum of 3 months, beyond the paediatric caseload seen in a general $A \& E$ setting.

\section{Discussion}

Although only $3.4 \%$ of total casualties, $32.9 \%$ of non-coalition casualties, were paediatric, the figure of $78.2 \%$ admission/transfer clearly indicates the high degree of acuity of those attending. Such a high figure thus has major resource and training implications. Terzic et al (1) analyzed war-related injuries in children seen at the Split University Hospital during the wars in Croatia and Bosnia between 1991 and 1995, and found a sample size of 94 treated children. The figure of 78 children seen in 36 days, therefore, represents a major caseload.

The high proportion of attending burns cases differs from other studies reporting the frequency of explosive wounds, finding that the major cause of morbidity in children with war injuries were either shelling/bombing or unexploded ordnance $(1,2,4,5)$. In terms of other trauma seen, it is of importance to note that Road Traffic Accidents were the second most important cause of other trauma after shrapnel wounding. Only one child sustained a Gun Shot Wound, which serves to highlight the fact that in this conflict children tended to be injured collaterally rather than as a result of being caught in crossfire. A percentage of 16.7 non-trauma presentations should serve as an important indicator that at time of conflict the disruption of normal health infrastructure could lead to morbidity in the less resilient paediatric population. Any medical unit potentially dealing with children affected by war should be prepared to see a wide range of childhood illness.

This study was based on a retrospective analysis of Accident \& Emergency registers and patient logs, and due to a clinical need to transfer promptly and a lack of IT or copying capability, a number of patients were transferred on without accurate records being retained at 34 Field Hospital. Only 38 of 78 children seen had accurate age recorded. This highlights a need for standardized special paediatric documentation, with copies to be held at the hospital where first seen, with emphasis being placed on the recording of such important paediatric parameters as age and weight.

Levels of paediatric qualification amongst deployed medical staff were reasonable, although there was a significant lack of any paediatric experience at senior house officer level. It has been proposed (7) that all clinicians involved in the paediatric clinical response to a civilian major incident be 
trained at least to the level of Advanced Paediatric Life Support (APLS) provider. This level of qualification was not met by the department studied, but is one which the RAMC should be attempting to provide if we are to meet equivalent standards of care to those in the NHS.

Paediatric injuries and illness, by the very nature of the patients concerned, require specialised paediatric equipment, taking into consideration the range of morbidity and range of age that are likely to be seen. In his 1999 paper (6), Mackway-Jones suggests a minimum level of supplementary equipment, which should be made available for receiving paediatric casualties. Table 3 shows the equipment required to manage 10 children.

Table 3. Minimum paediatric equipment for 10 children.

\begin{tabular}{|l|l|l|}
\hline & Item & Number \\
\hline Airway and Cervical Spine & Airways 00-2 & 5 each \\
\hline & $\begin{array}{l}\text { Endotracheal tubes } \\
2.5-6.5\end{array}$ & 5 each \\
\hline & $\begin{array}{l}\text { Yankauer sucker } \\
\text { (paediatric) }\end{array}$ & 10 \\
\hline & Soft sucker 8-10g & 10 each \\
\hline & $\begin{array}{l}\text { Semirigid cervical } \\
\text { collars (paediatric) }\end{array}$ & 5 sets \\
\hline Breathing & $\begin{array}{l}\text { Child self inflating } \\
\text { bag }\end{array}$ & 2 \\
\hline & Face masks 00-2 & 1 each \\
\hline & $\begin{array}{l}\text { Oxygen masks with } \\
\text { reservoir (paediatric) }\end{array}$ & 10 \\
\hline & Chest drains 24-28F & 2 each \\
\hline Circulation & $\begin{array}{l}\text { Venous Cannulae } \\
18-24 g\end{array}$ & 20 each \\
\hline & Intraosseous cannulae & 2 \\
\hline & 50 ml Luer lock syringes & 2 \\
\hline & Giving sets (paediatric) & 20 \\
\hline & $\begin{array}{l}\text { ECG electrodes } \\
\text { (paediatric) }\end{array}$ & 25 \\
\hline & $\begin{array}{l}\text { Defibrillation pads } \\
\text { (paediatric) }\end{array}$ & 2 pairs \\
\hline & Urinary catheters 8-10g & 2 each \\
\hline & Nasogastric tubes 8-10g & 2 each \\
\hline & $\begin{array}{l}\text { Weight-height or } \\
\text { weight-age nomogram } \\
\text { Eg Broselow tape }\end{array}$ & 1 \\
\hline & Spinal board (paediatric) & 1 \\
\hline & Other & \\
\hline & & \\
\hline & &
\end{tabular}

Additionally as discussed previously, weight is an important parameter in the management of paediatric emergencies, and thus any deployed Accident \& Emergency department should have facility to weigh children of all ages.

\section{Conclusion}

War fighting produces paediatric morbidity. Any medical unit deploying in support of a conflict situation needs to be prepared to receive traumatic and non-traumatic paediatric cases. This needs to be taken into account when planning the medical support to military operations. Specialist qualifications and experience are essential in the management of the seriously ill child, and provision should be made for the specialist paediatric equipment required. Further discussion is clearly indicated if we are to be able to provide appropriate levels of care for these most innocent of victims of war.

\section{Acknowledgements}

The author would like to acknowledge the assistance of Col T Hodgetts and the other medical staff of $34 \mathrm{Fd} \mathrm{Hosp.}$

\section{References}

1. Terzic J, Mestrovic J, Dogas Z, Furlan D Biocic M Children War Casualties during the 1991-1995 Wars in Croatia and Bosnia and Herzegovina. Croat Med J 2001; 42(2):156-160.

2. Garfield RM, Neugot AI. Epidemiological analysis of warfare, a historical review. $\mathcal{F A M A}$ 1991;266:688-92.

3. Pearn J. Children and war. J Paediatr. Child Health 2003; 39:166-72.

4. VanRooyen MJ, Sloan EP, Radvany AE, Peric T, Kulis B, Tabak V. The incidence and outcome of penetrating and blunt trauma in central Bosnia: the Nova Bila Hospital for war wounded. F Trauma 1995; 38:863-66

5. Slater PE. The Gulf War and mortality in Israel. Lancet 1991; 338:1336.

6. Mackway-Jones, Carley S, Robson J. Planning for major incidents involving children by implementing a Delphi study. Arch Dis Child 1999;80:410-413.

7. Advanced Life Support Group. Advanced paediatric life support: the practical approach. 2nd ed. London: BMJ Publishing Group, 1995. 